\title{
Investigating the Relationship between Intellectual Capital and Financial Performance in Cement Sector firms in Pakistan
}

\author{
ALAM REHMAN \\ National University of Modern Languages, Peshawar \\ amrehman@numl.edu.pk \\ ADIL KHAN \\ MS - Scholar National University of Modern Languages, Peshawar \\ FARMAN ULLAH \\ MS - Scholar National University of Modern Languages, Peshawar \\ Farman_ghazni@yahoo.com

\section{Abstract} \\ The study examines the relationship between intellectual capital performance and \\ financialperformance of cement sector firms listed on Pakistan stock exchange. The study \\ has been conducted using human capital, structural capital and relational capital as the \\ determinants of intellectual capital and return on assets as the proxy of financial \\ performance. The study applies random sampling technique for 20 cement sector firms \\ for the period 2007 to 2016. The study uses correlation and simple OLS to test the \\ hypothesis. The results reveal that intellectual capital as a composite and all its \\ determinants i.e. human capital, structural capital and relational capital have positive \\ significant impact on the financial performance of cement sector firms. The study has \\ practical as well as theoretical implications. The results are expected to help policy \\ makers to rehash their policies by encompassing the approaches that facilitate the \\ intellectual capital of their firms. The study will also help researchers in strengthening \\ their level of understanding of these relationships. Replication of the study may help to \\ validate the hypothesized model and their consequent application in the organizations \\ that share somewhat similar organizational structures.
}

Key words: Intellectual capital, Correlation, Regression, Cement Sector, Pakistan.

\section{Introduction}

The area of intellectual capital has been explored in the developed nations and the sae is found very limited and scarce in developing countries like Pakistan. The developed world has recognized the importance of intellectual capital as the important financial performance indicator, helping in their competitive advantage. However few of the studies in this field have examined the same in developing countries like its measurement, valuation and the disclosure practices of the intellectual capital (Kamath, 2008). Intellectual capital has got much importance and attention in the minds of researchers. Due to the conduction of these researchers, it has been widely explored by 
many researchers (Abesyekera and Guthrie, 2004).The Business environment has changed a lot in nearest past. The Competition across the organizations to have core competence has been emerged and is considered very important.The companies now mostly focusing on their intangible assets as there is moving diversion of the companies from production concern to service concerns. So the importance of intangible assets has increased. Innovation and creation is mainly due to the best practices of intangible assets. Similarly, a study was also conducted by Roos (2012) who argues that organizations is highly dependent upon the human capital, as human can contribute as up gradation and development of the organization. Due to this reason the element of human capital is very vital for heavily competitive edge. Considerable importance performance of h-capital generates the perfect sustainability and utmost success for the firms in future. So organizations are intended to maximize the human capital resources effectively and efficiently utilize it, in best direction to obtain results in term of profitability productivity. (Roos, Pike andFerstrom, 2012).

In business the level of capital predicting the types of assets and its cash flows determine the tangible worth of the assets of the company and the value of the assets determine the level of the firs detriments and the strength of the company can be revealed by the types of assets it has. The value containing by these assets can be determined by the company's balance sheets and other financial records.. So in this regard various assets as machinery, building, land and other assets of infrastructure play a key role. While the portfolio of financial assets are working capital, share owners' equity, retained earnings, prepaid expenses, and accounts receivable etc. In the other hands intangible assets are such kinds of assets as the skills and knowledge of employees who work and its environment, are largely cater the important to tell about the future view of the company.

Therefore the various kind of these assets are vital for both internal and external assessments and the same predicting the portfolio of these assets and as perThomas Stewart also impressed with the portfolio of tangible assets which help to determine and createthe firm's value,discussed the importance of $\mathrm{HC}$, the SC and the RC.While in contrast, Kamran (2008) argued about the importance of the firm IC and its association with profitability. They analyzed 150 firms for the purpose of analysis and applied correlation and regression techniques and evidenced vital impactdekivered by the IC to the profitability of the various firms.

The firm's Human Capital(HC) contains details about employee's skills, knowledge and talent that are very important to perform the everyday or routine duty tasks, which are closely related to the firm's core strategy.

While the Structural Capital (SC) represent the firm's knowledge applications systems, information system and databases systems, processes system andsome other infrastructure which help and facilitate the strategy of the firm. Similarly Relational Capital (RC) represents the outsider associations of the companies supplier and their customer that gives intellectual support to facilitate and also to makes available thesaling of goods as well as services in an effortless manner or to takes account of the informationintegrated in the kind of business network, which pertains therelationship of the outside the businesse.g the level of loyalty the goodwill and the supplier relations. 
Young et al. (2006) documented in his study that the industrial revolution which start from the mid- $18^{\text {th }}$ century in UK was a great changeover to newly manufacturer procedure that have cause a huge scale production. Those firms whichhave easily approached to some new and advance manufacturing system or machineries, equipment, and so on and also have sufficient assets will must have leading position at their competitive world. While as on $21^{\text {st }}$ century the success of any economy is closely dependent upon the knowledge, information, skills, innovativeness, creativity and critical thinking to lunch very new product in market. The equipment of innovation and creativity are gained from the knowledge and thoughts of concerned employees. Through olderways preparing a financial report worksheets have not be measured and considered as cost efficient and suitable.

In previous studies,Bonits et al. (2000) examined and explored the association and linkage of IC and the firms proxies of FP and reported that the fir VAIC is vital to influence the profitability and suggested that firs should take their firms well equipped in term of the intellectual practices. The study admired the contribution of intellectual practices which will definitely encourage the momentum of the IC. Therefor the corporations have recently focused on the importance and usefulness of thefirmintellectual capital which is very invisible and at the same timealso the intangible resources of the organizations to replace the old archaism and style of financial reporting (Young et al., 2006).

Roos et al. (1997) also explained and documented the association and linkage of IC and the proxies of profitability and strongly argued about the significance and importance of the i- capital and found that it positively affects the various proxies of the profitability of the firm and its growth.He argues that all these objectives can be obtained through modern measures of accounting. While In this research study IC is measuredthrough SC, H-capital, and R-Capital with the help of using pulic (2000) VAIC model which is so called pulic model. Pike and Ferstrom. (2012) also confirmed and portrayed that IC has greater influence on firm proxies of financial performance. While young et al. (2006) in sane kind of study evidenced that IC is having totally insignificant statistical linkage with the firm's FP various determinants. Pulic (2000) determined the significance of the IC and highlighted that IC is by no means the determing element which can produce and foster growth for the firm in both tangible and kind of intangible ways. While in contrast, Dias (2000) also evidenced results confirm the findings of those who are viewing the positive significant impact on and relationship of Intellectual Capital (IC) and Financial Performance (FP), similarly the linkage of IC and market capitalization has also been analyzed by some previous researchers documenting positive trend of relationship of the IC and the determinants of the profitability (Abesyekera and Guthrie, 2004; Roos, Pike and Ferstorm, 2012).

Wang (2011) analyzed non-financial firm for investigating the relationship and associationof i-capital (IC)and the FP and found that intellectual part of the capital can greater effect the profitability of firm. Similarly, Chang (2007) also investigated and assessed the magnitude of relationship and link between the IC and FP and evidenced agreater positive underlyingeffect of $i$ - capital on the firm level of profitability. While in 
contrast, Very few studies have been conducted, investigating the relationship between financial performance and market capitalization. Like Sultan (2014) analyzed the relationship between financial performance financial performance and market capitalization. The study found that as the financial performance increases of a firm, it will directly affect the market capitalization positively. This study is conducted with the aim to achieve the following objectives.

1. To measure and evaluate the intellectual capital performance of the listed firms in cement sector on Pakistan stock exchange.

2. To examine and investigate the impact of intellectual capital on the financial performance of these listed firms.

\section{Literature Review}

Itami (1987) investigated that intellectual capital among all capitals is the most important and vital value indicator of the business organization for the growth in this smart and aggressive capitalistic globe; still it has faces so many obstacles remain to be clear regarding its introduction and definition as well. So till to date intellectual capital is not defined in the same way across the world and sectors. Itami(1987) was one of the earlier contributors who define the i- capital as the sort of intangible assets that comprises of firms technology, loyalty of customer, the brand name, trademark, goodwill of the firms and so on. Similarly Stewart (1997) has documented in his study regarding intellectual capital definition, he asserts that i- capital is all about the concept that describe all three elements of the same IC. He furthermore explained that human capital is the combination of the sum of innovativeness, creativity, skillful employees, employees thinking, employees mindset, seniority of employees, employees turn-over rate, employees experiences, and some other skills like learning skills of employees. While keeping in view the structural capital is the kind of availability of knowledge though collection of highly using the most efficient and effective tested, incorporated, organized as with the irrelevant portion separated out before division.

While in similar studyEdvisson and Malonev (1997) describe that intellectual capital is the mixture of some components like H-capital, S-capital and R-capital. Bontis et al. (2000) argued that successful corporations taking care of their employees knowledge instead of their tangible assets for example the building, land and machinery. As employees knowledge isthe backbone of the company's development. A financial statement such as balance sheet does not show the true value creation of those activities obtained through its intangible assets. The analysis strongly predicted the greater contribution of the firm's i-capital in uplifting the FP and firm's growth. This competitive knowledge has deeply focused on the skills and the kind of competencies and terms them very vital for the business i.e. intellectual capital.Roos et al. (1997) asserted and documented the association and linkage of IC and the proxies of profitability and strongly argued about the significance and importance of the i- capital and found that it positively affects the various proxies of the profitability of the firm and its growth. He argues that all these objectives can be obtained through modern measures of accountingSimilarly, they have argued that the firm'sintellectual capital vitally significant to positively significantly determine the financial performance and future cash flows. 
Intellectual capital has got much importance and attention in the minds of researchers. Due to the conduction of these researchers, it has been widely explored by many researchers (Abesyekera and Guthrie, 2004).The Business environment has changed a lot in nearest past. The Competition across the organizations to have core competence has been emerged and is considered very important. The companies desperately trying for the growth in view of the firms intellectual assets. The companies now mostly focusing on their intangible assets as there is moving diversion of the companies from production concern to service concerns. So the importance of intangible assets has increased. Innovation and creation is mainly due to the best practices of intangible assets. Similarly, astudy in the same area was also conducted by Seviby (1998) who represents the kinds of I-Capital performance and its linkage with and influence on the internally structure and externally structure with the individual or employees competences need to deal with situation andconcerned with some stated or disclosed information, knowledge, creative skills, practical experiences, value related judgment and social network, In the other hand internal structure being the combination or sum of the evident or patents documents controlled, various concepts, the patterns, different computer skills and various management systems, however the other hand of external structure which is communication of customers with suppliers, which contains mainly the brand name, the goodwill, well reputation and trademarks etc.

Johnson (1999) have investigated that intellectual capital is the combination of some components i.e.the h-capital, the s-capital and last one is the r-capital, in whichthe human capital are treated as the ideal capital. It represents the employee's skill, knowledge, attitude and talent. In context to this study structural capital represents the innovative capital which will be comprises as the trade marks, patents, copyrights and knowledge application as well and combined with process capital as work procurements and business secrets; similarly relational capital indicates the association of class and relationship with the customers, suppliers and group of interconnected global world.

Edvinsson and Malone.(1997)Argued that human capital is pertaining and covers the individual talent, skills, informative knowledge, competencies and the experiences expertise of the whole or entire of thestaff members and the management specially of a corporation, comprises of the creativeness and innovativeness as well as the capacity of the corporate organization. The study revealed the importance of the i-capital in positively contributing to the firms. The combination of these capital greatly affect the growth mechanism of the firm positively. While in the other hand the s- capital is a defensive framework which paid physical shape and balance of power to the underlying h-capital which consists of some tangible system using for the relationship and communication or for safeguarding of intellectual material. Similarly r-capital refers to the satisfaction of the customer, strength, price stability and the financial power for the various long term loyal clients.

Marr and Roos. (2005) have also demonstrated in a study in which they have investigated that the i-capital can be determining element to affect the financial performance of firms. They argued that intellectual capital can be considered as a thoughtful as well as knowledge founded assets of the organization. In organization should needs to 
determined that how much and how possibly change in these intangible assets can helps to keep vital and crucial important objectives toward the effort and value of the organization. Similarly they have asserted that the property growth can be achieved with the help of some knowledge based economy. Furthermore they haveassertedthe intellectual capital as a key indicator of the financial performance. In this context the underling literature indicates the valuable importance relating toIC and the profitability of the firm.

Miller et al. (1999) also conducted a similar study, in which they are described the feelings of manager toward the vitality and validity of the i-capital. In this regards, they explained that manager have widely and greatly stressed on intellectual capital performance with the firm's determinates of the profitability of the firm and they concluded the positively built effect of intell- capital on the firm'sFP. The study desperately revealed the importance of all these capital to strengthen the base of the firm. Similarly, Van Buren (1999) documented that i-capital is closely related with the firm's financial position and performance. Low (2000) observed the significance and importance of the IC specially the non-financial assets categories and its effect on company financial performance. He found, it significantly associated with one another. Riahi-Belkaoui (2003) has examined and investigated the relationship of i-capital with proxies of financial performance.

The obtained results of the study show the positive and significant correlation of intellectual capital with the firm's financial performance. He asserted further that the circumstances must be collective with to highly maximize the company performance. Some other empirical studies that show the kind of positive and statistically significant influence of the various non-physical assets on both of the firm's financial performance and inventory returns(Wright et al., 1994). Wang (2011) also assessed and analyzed the various non-financial firms for investigating the relationship and association of i-capital (IC) and the FP and the results predicted through regression found that intellectual part of the capital can greater effect the profitability of firm. Similarly study was conducted by Aboody and Lev (2000) which shows the impact of intellectual capital onthe current and on the future operating sources of earnings which represented very strong correlation. According to some other field of studies like chemical industry have also highlighted and showed that increase in R\&D- investment would have really doubled the operating gains and profits (Low, 2000).

Muhammad and ismail (2009) conducted a study using 18 Malaysian financial firms, and found a positive and statistically significant impact of the firm's intellectual capital on financial performance. Similarly,Knappet al. (1999) suggest that when a firm efficiently manages their resources of intellectual capital will be more able to obtain a kind of superb and dynaic competitive edge over their competitors or other companies and will also be better than those companies which have not some proper control over their human resources. Similarly, Ting and Lean (2009) have also conducted a study in the same area and mentioned that financial performance and intellectual capital have positively and significantly associated with each other. During their study they used pulic model of VAIC, the results of study show that i-capital and return on assets have positively linkage 
and statistically significantly associated with each other. Furthermore the study results revealed that all the three kinds of VAIC elements closely and positively associated with firm's profitability.

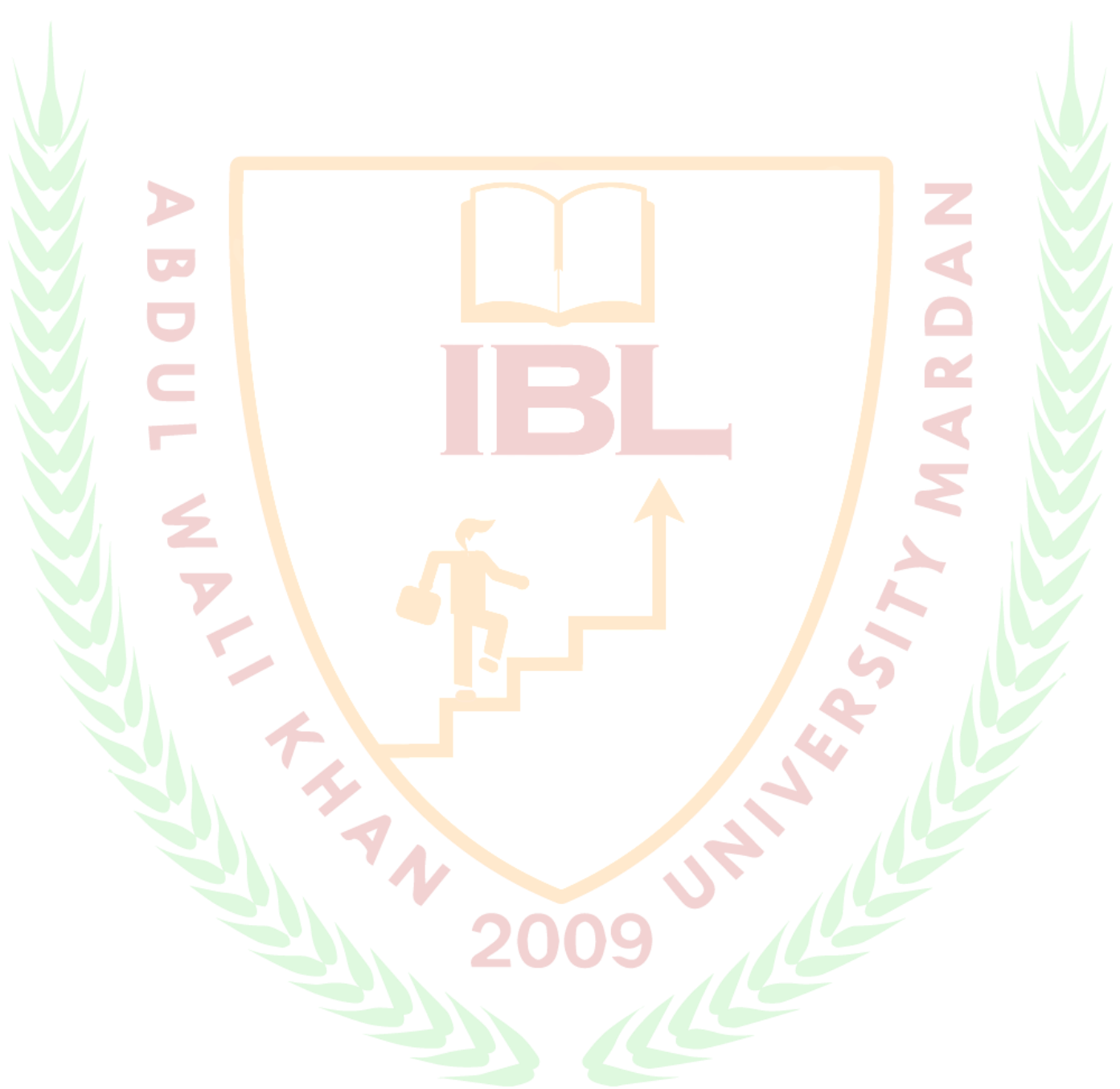




\section{Theoretical Framework}

After the review of relevant literature, the following theoretical framework has been developed.

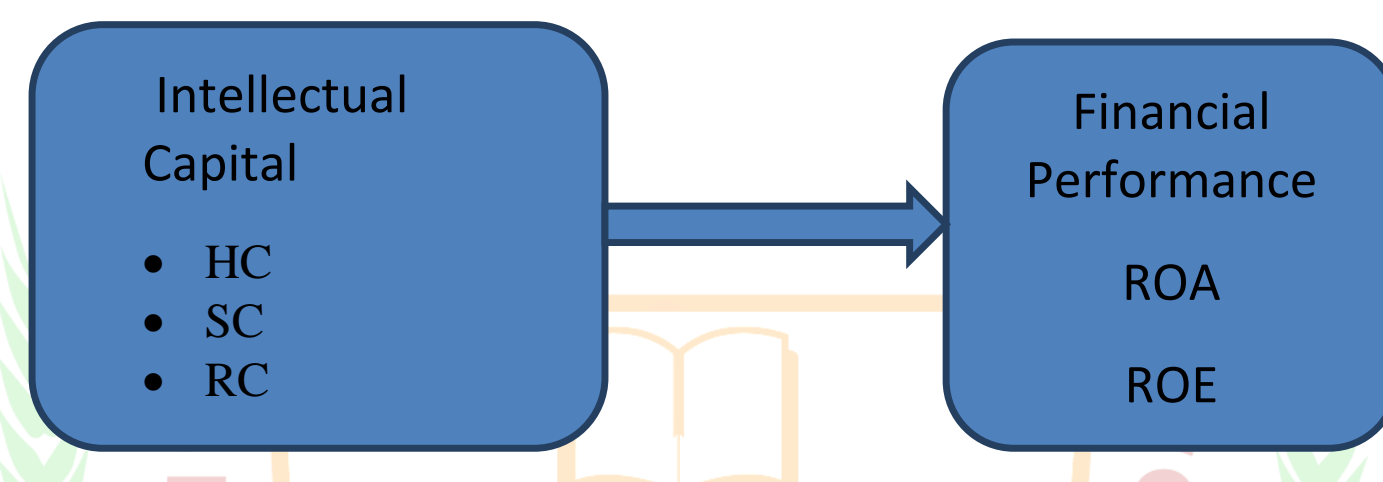

\section{Research Hypothesis}

H1. Intellectual capital has positive significant impact on the financial performance.

H2. Human capital has positive significant impact on the financial performance.

H3. Structural capital has positive significant impact on the financial performance.

H4. Relational capital has positive significant impact on the financial performance.

\section{Operational Definitions and Measurement}

\section{Value Added Intellectual Coefficient (VAIC)}

Value added intellectual coefficient can be used to determine, analyze and to measure the economic income as well as to measure the level of intellectual capital toward contribution and value creation of the firms. pulic (2000) measured the IC as VAIC= $\mathrm{HCE}+\mathrm{SCE}+\mathrm{RCE}$. So in this study the same above measurement technique is followed for the calculation of firm's intellectual capital.

\section{$\mathrm{VAIC}=\mathrm{HCE}+\mathrm{SCE}+\mathrm{RCE}$}

HCE means the human capital efficiency, SCE represents the structural capital efficiency, RCE represent Relational capital efficiency, in this study intellectual capital can be represents as the sum of human capital, structural capital and relational capital.

Human capital $=$ Value added $/$ Human Capital

Structural capital $=$ Structural Capital $/$ Value Added

Relational capital $=$ Value Added $/$ Relational Capital

So the above mention variables of the model can be measured through using the following procedure:

$\mathrm{VA}=$ Output - Input

Here in this study where inputs of the firms are represented by its resources and costs while in the other hand output consists upon revenues of the firms. However, Stahle and Aho (2011) have also provided some different way to measure the value added:

Value Added $=$ Operating profits + Cost + Depreciation + Amortization

VAIC represent whole of the three dimensions.

Where as 
Human Capital $=$ Cost of employee wages + salaries

Structural Capital $=$ VA $-\mathrm{H}$ - Capital $=$ Operating profit + Depreciation + Amortization

However the value of RC can also be measured by deducting value of intangible assets from total assets of the company.

Relational Capital $=$ Total Assets - Intangible Assets

\section{Return on Assets (ROA)}

Return on Assets is the measure of financial performance, which will be measured as, Net Profit / Total Assets of a firm. The same measure was used by Costa (2008).

\section{Model Specification}

The following models have been used to test the hypothesis of the study.

\section{$\mathrm{ROA}_{i t}=\beta_{0}+\beta_{1} \mathrm{IC}_{\mathrm{it}}+\beta_{2} \mathrm{HC}_{\mathrm{it}}+\beta_{3} \mathrm{RC}_{\mathrm{it}}+\beta_{4} \mathrm{SC}_{\mathrm{it}}+\mathrm{eit}_{\mathrm{it}}$}

\section{Research Methodology}

Types of Research

This is a quantitative research study. The data was quantitatively analyzed.

\section{Population and Sampling}

The population is the total number of observations available in any sitting for the research or investigation. The population of this study is all listed firms of cement sector firms in Pakistan. This study applies random sampling technique for the data analysis of this research. Total 20 firm's data was included in the data analysis for the period of 2007 to 2016.

\section{Data Collection and Techniques}

The data for the analysis of study was collected from the annual reports of the firms, relevant data available on Pakistan stock exchange and data available on the state bank site also used.

\section{Statistical Techniques and Tools}

The data of this study was analyzed through statistical techniques like Correlation and regression.

\section{Correlation Analysis}

\section{Results and Discussion}

The table 1 shows the results of a correlation of the study. The results indicate that intellectual capital is positively significantly correlated with the firm financial performance proxy, i.e, return on Assets. This documents that as the value of this ratio increases therewill be an increasein the financial performance. The correlation results also reveals that $\mathrm{HC}, \mathrm{SC}$ and $\mathrm{RC}$ significantly positively correlated with the financial performance proxy i.e. ROA, which indicate that as the level of firm $\mathrm{HC}, \mathrm{RC}$ and SC increases than the FP proxies of a firm tends to increase.

\begin{tabular}{lcccc}
\multicolumn{5}{c}{ Table 1:Pearson Correlations analysis } \\
\hline $\begin{array}{l}\text { Variables } \\
\text { RC }\end{array}$ & ROA & IC & HC & SC \\
\hline ROA & & & & \\
\hline Rehman, Khan \& Ullah & & 59 & & ISSN: 2520 - 0739
\end{tabular}




\begin{tabular}{lllll}
\hline IC & .266 & 1 & & \\
$\mathrm{HC}$ & .210 & .199 & 1 & \\
$\mathrm{SC}$ & .123 & .024 & .130 & 1 \\
$\mathrm{RC}$ & .143 & .196 & .129 & .021 \\
1 & & & & \\
\hline
\end{tabular}

\section{Regression Results}

Table 2 shows the effects intellectual capital and their determinants on the financial performance of cement sector firms in Pakistan. The results document a positive significant impact of IC on the financial performance, as the tabulate T-value is 2.123, which is significant at $5 \%$ probability level. The results also report positive significant impact of the intellectual capital, determinants i.e. HC, SC and RC. All these three variables showing positive significant impact on the financial performance proxy. The $t$ values of all these three variables are significant at 5\% probability level. The explanatory power of the model is quite satisfactory as the R-square value tabulated is 0.45 , which documents that $45 \%$ changes in financial performance (ROA) is caused by the set of predicating variables of the study. The F- value is statistically significant at $5 \%$ probability level, which indicates that the overall model is statistically fitted and significant. The muilticolinarity statistics show that there is no muilticolinarity issue in the data. The tabulated values of tolerance and variance inflation factor (VIF) are within the acceptable ranges, thereby documenting that no muilticolinarity issue in the data of the study. As per Gujrati (2004) the value of VIF for a variable should not exceed 10, however the tabulated values of all explanatory variables are less than 2 , which predict non- existence of muilticolinarity in the data.

Table2:Regression results

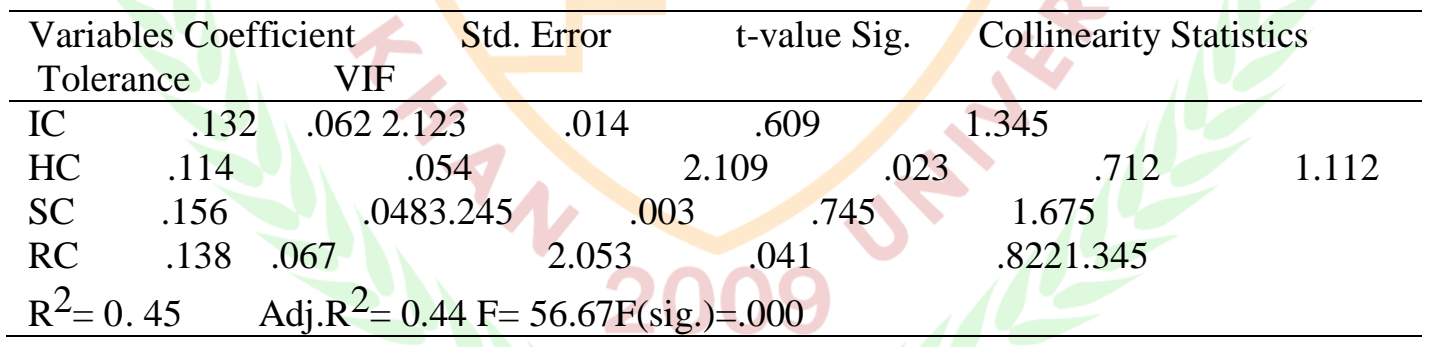

\section{Conclusion}

The study has been conducted with the aim to find and investigate the relationship between intellectual capital and financial performance of cement sector firms. The study has been conducted using intellectual capital as composite and its determinants i.e. HC, SC and RC and Return on asset has been used as the proxy of the financial performance. The study has used random sampling technique for the 20 cement sector firms for the period 2007 to 2016. The final results have been predicted on the bases of simple OLS and correlation. The results revealed that intellectualcapital as a composite has positive significant impact on the financial performance.Muhammad and Ismail 
(2009) also predicted similar findings. The results indicate that $\mathrm{HC}$ has positive significant impact on the financial performance, which is in line to the findings of previous researcherswho also viewed the importance of all three dimensions of IC. Similarly the results found that SC and RC have positive significant impact on the financial performance. Similar findings were documented by Stahle and Aho (2011). The study has some policy implications. This study will help the decision makers and top management of the cement sector to overlook on these key areas of their firms to tighten their polices and take remedial actions if they feel weaknesses in the practices of intellectual capital. Similar studies can be conducted in future using market capitalization as another dependent variable or mediating variable. Similar studies can also apply structural equation modeling rather than simple OLS.

\section{References}

Abeysekera, I., \& Guthrie, J. (2004). How is intellectual capital being reported in a developing nation?.

Aboody, D., \& Lev, B. (2000).Information asymmetry, R\&D, and insider gains. The journal of Finance, 55(6), 2747-2766.

Ali, I. M., Kamarudin, K., Suriani, N. A., Saad, N. Z., \&Afandi, Z. A. M. (2010). Perception of employers and educators in accounting education. Procedia Economics and Finance, 54-63.

Al-Nimer, M., \&Sleihat, N. (2015). The Effect of Profitability Ratios on Market Capitalization

in Jordanian Insurance Companies Listed in Amman Stock Exchange. Journal of Economics and Sustainable Development, 6(6).

Bharath, K., G. (2008). Intellectual capital and corporate performance in Indian pharmaceutical industry. Journal of Intellectual Capital, 9(4), 684-704.

Bontis, N. (1998). Intellectual capital: an exploratory study that develops measures and models. Management decision, 36(2), 63-76.

Bontis, N., Chua Chong Keow, W., \& Richardson, S. (1997). Intellectual capital and business performance in Malaysian industries. Journal of intellectual capital, 1(1), 85100 .

Bontis, N., Chua Chong Keow, W., \& Richardson, S. (2000). Intellectual capital and business performance in Malaysian industries. Journal of intellectual capital, 1(1), 85100 .

Bornemann, M., Knapp, A., Schneider, U., \&Sixl, K. I. (1999, June). Holistic measurement of intellectual capital. In International Symposium Measuring and Reporting Intellectual Capital: Experiences, Issues and Prospects. June. Amsterdam. Campisi, D., \& Costa, R. (2008). A DEA-based method to enhance intellectual capital management. Knowledge and Process Management, 15(3), 170-183.

Carter, J. C., Stewart, D. A., Dunn, V. J., \& Fairburn, C. G. (1997). Primary prevention of eating disorders: might it do more harm than good?. International Journal of ICPerformance, 22(2), 167-172. 
Djamil, A. B., Razafindrambinina, D., \&Tandeans, C. (2013). The Impact of Intellectual Capital on a Firm's Stock Return: Evidence from Indonesia. Journal of Business Studies Quarterly, 5(2), 176.

Edvinsson, L., \& Malone, M. S. (1997). Intellectual Capital: Realizing Your Company's True Value by Finding Its Hidden Brainpower.

García-Meca, E., Parra, I., Larrán, M., \&Martínez, I. (2005). The explanatory factors of intellectual capital disclosure to financial analysts. European Accounting Review, 14(1), 63-94.

Guenthera, M., \&Sleihat, N. (2015). The Effect of Profitability Ratios on Market Capitalization in Jordanian Insurance Companies Listed in Amman Stock Exchange. Journal of Economics and Sustainable Development, 6(6).

Itami, H., \& Roehl, T. (1987).Mobilizing intangible assets. Cambridge (Mass.).

Jaggi, B., \& Low, P. Y. (2000). Impact of culture, market forces, and legal system on financial disclosures. The International Journal of Accounting, 35(4), 495-519.

Johnson, R. A., \& Greening, D. W. (1999). The effects of intellectual capital and institutional ownership types on corporate social performance. Academy of management journal.

Marr, B., \&Roos, G. (2005).A strategy perspective on intellectual capital. Perspectives on intellectual capital, 28-41.

Muhammad, N. M. N., \& Ismail, M. K. A. (2009). Intellectual capital efficiency and firm's sperformance: Study on Malaysian financial sectors. International Journal of Economics and Finance, 1(2), 206.

Ousama, A. A., Fatima, A. H., \& Hafiz Majdi, A. R. (2011). Usefulness of intellectual capital information: preparers' and users' views. Journal of intellectual capital, 12(3), 430-445.

Petty, R., \& Guthrie, J. (1998). Intellectual capital literature review: measurement, reporting and management. Journal of intellectual capital, 1(2), 155-176.

Pulic, A. (2000). VAIC ${ }^{\text {TM}}$-an accounting tool for IC management. International journal of technology management, 20(5-8), 702-714.

Riahi-Belkaoui, A. (2003). Intellectual capital and firm performance of US multinational firms: a study of the resource-based and stakeholder views. Journal of Intellectual capital, 4(2), 215-226.

Torrance, R., \& James, D. (2009). The state-of-the-art in IC reverse engineering.

In Cryptographic Hardware and Embedded Systems-CHES 2009 (pp. 363-381). n Wang, S., Wilkes, A., Zhang, Z., Chang, X., Lang, R., Wang, Y., \&Niu, H. (2007). Management and land use change effects on soil carbon in northern China's grasslands:

Wei Kiong Ting, I., \&Hooi Lean, H. (2009). Intellectual capital performance of financial institutions in Malaysia. Journal of Intellectual capital, 10(4), 588-599. 